\title{
Response of polyisoprenoid concentration and profile in three groups of mangrove seedlings of coping with long-term salinity
}

\author{
MOHAMMAD BASYUNI ${ }^{1,2, \bullet}$, HIROSHI SAGAMI ${ }^{3}$, SHIGEYUKI BABA ${ }^{4}$, HIROSUKE OKU $^{5}$ \\ ${ }^{1}$ Department of Forestry, Faculty of Forestry, Universitas Sumatera Utara, Jl. Tri Dharma Ujung No. 1 Medan, North Sumatera, 20155, Indonesia. \\ Tel./fax: +62-61-820-1920. `email: m.basyuni@usu.ac.id \\ ${ }^{2}$ Mangrove and Bio-Resources Group, Center of Excellence for Natural Resources-Based Technology, Universitas Sumatera Utara. Padang Bulan, \\ Medan 20155, North Sumatera, Indonesia \\ ${ }^{3}$ Institute of Multidisciplinary Research for Advanced Material, Tohoku University. 2-1-1 Katahira, Aoba-ku, Sendai, 980-8577, Japan \\ ${ }^{4}$ International Society for Mangrove Ecosystems, Faculty of Agriculture, University of the Ryukyus. 1 Senbaru, Nishihara, Okinawa 903-0213, Japan \\ ${ }^{5}$ Molecular Biotechnology Group, Tropical Biosphere Research Center, University of the Ryukyus. 1 Senbaru, Nishihara Okinawa 903-0213, Japan
}

Manuscript received: 24 November 2018. Revision accepted: 29 December 2018.

\begin{abstract}
Basyuni M, Sagami H, Baba S, Oku H. 2019. Response of polyisoprenoid concentration and profile in three groups of mangrove seedlings of coping with long-term salinity. Biodiversitas 20: 320-326. The response of polyisoprenoid (polyprenol and dolichol) concentration and distribution was investigated with three groups mechanism of coping with salinity: a secreting mangrove species of Avicennia officinalis, a non-secreting species (excluder) of Bruguiera cylindrica, and a salt-accumulating species of Xylocarpus granatum. The seedlings of three mangroves were grown under 0 and $3 \%$ salinity concentration for five months. Polyisoprenoids in the lipid extracts were examined by two-dimensional thin layer chromatography (2D-TLC). The pattern of the polyprenols and dolichols in the leaves and roots were categorized as two types (I and II). In category I, dolichols dominated over polyprenols, however, in category II, the existence of both polyprenols and dolichols was found. In the leaves, type-I was observed in $A$. officinalis under 0 and 3\% salinity. On the other hand, type-II was found in B. cylindrica and X. granatum under 0 and $3 \%$ salt concentrations. A similar pattern was found in the roots, A. officinalis (type-I), and that in B. cylindrica and X. granatum was type-II. This finding depicted that the seedlings of A. officinalis, B. cylindrica, and X. granatum leaves and roots imply no change in the distribution type: the categories were distributed as type I or II under $0 \%$ salt concentrations, as well as type-I or II under $3 \%$ salt concentrations. This study implied that polyisoprenoids may play a protective function against salinity in the mangrove leaves and roots of three groups scheme (secreting, excluding, and accumulating) of salt management.
\end{abstract}

Keywords: Dolichols, mangrove, polyprenols, protective role, secreting and non-secreting species

\section{INTRODUCTION}

Mangrove forests are widespread in the intertidal area of tropical and subtropical areas and are denoted physiologically by their ability to grow under varying salinity concentration, differing from freshwater to seawater conditions (Tomlinson 1986; Basyuni et al. 2017a). Mangrove plants are categorized into three groups according to their mechanisms of coping with salinity, i.e., salt-secreting, non-salt-secreting or excluder, and salt accumulating (Tomlison 1986; Hogarth 1990; Basyuni et al. 2017a). The salt secreting species includes Avicennia officinalis (Acanthaceae), which has salt glands or salt hairs to eliminate excessive salt. The non-secreting species (salt exclusion) is exemplified by Bruguiera cylindrica (Rhizophoraceae), which has no salt glands but an ultrafiltration scheme. The salt accumulators species such as Xylocarpus granatum can cope with high salinity levels in their cells. A. officinalis, B. cylindrica, and X. granatum are common mangrove species on Lubuk Kertang forest, Langkat, North Sumatra, Indonesia and are considered to be the type of every group in concern of salinity characteristics. The three species are therefore are ideal exemplary for studying physiological mechanisms of salinity tolerance at biochemical level.
Although mangroves are well known to produce secondary metabolites along with polyisoprenoid alcohols, the physiological function of these compounds remains poorly understood (Basyuni et al. 2016, 2017a, 2018a). Polyisoprenoid is a secondary metabolite compound with a linear polymer unit of five carbon chains found in almost all living cells (Swierzewski and Danikiewicz 2005; Basyuni et al. 2016, 2017b, 2018a; Sagami et al. 2018). Our previous studies have shown that salinity enhanced the triterpenoid content and triterpenoid synthase genes in mangrove seedlings (Basyuni et al. 2009, 2012a,b). By contrast, salinity decreased the mangrove seedling growth (Basyuni et al. 2009, 2012a,b, 2014; Hoppe-Speer et al. 2011; Ye et al. 2005). These studies suggested the complexity and diversity level of mangrove species. It is essential, therefore, to investigate the salt tolerant mechanism of each species of mangroves. At present, we are the first group to show that the salinity changes polyisoprenoid concentration in mangroves seedlings (Basyuni et al. 2017a). The present study extends our previous study and describes the response of polyisoprenoid (polyprenol and dolichol) content and distribution in three groups of salinity coping salinity, i.e., a secreting mangrove species of Avicennia officinalis, a non-secreting species of Bruguiera cylindrica, and a salt- 
accumulating of Xylocarpus granatum.

\section{MATERIALS AND METHODS}

\section{Plant materials}

Mature and healthy propagules (seeds) of salt-secreting species, Avicennia officinalis L. (Acanthaceae), a nonsecreting (excluder) species, Bruguiera cylindrica Blume (Rhizophoraceae), and a salt-accumulating species, Xylocarpus granatum Koen (Meliaceae) were collected in Lubuk Kertang forest, Langkat, North Sumatra, Indonesia and planted in bottle pots under 0 and $3 \%$ salinity level in a glass house. Mature seeds of A. officinalis had a greenish yellow pericarp with dark green to russet endosperm, 2.5$3.0 \mathrm{~cm}$ long and $2.0-2.5 \mathrm{~cm}$ wide. The mature propagules of $B$. cylindrica was slightly curved, cylindrical fruit hypocotyls with green to purplish green color, $0.5-1.0 \mathrm{~cm}$ in diameter, and $10-15 \mathrm{~cm}$ in length; mature $X$. granatum seeds were yellowish brown with a durable surface, greenish yellow cotyledons and were $15-20 \mathrm{~cm}$ in diameter. The $X$. granatum fruit is heavy $(1-2 \mathrm{~kg})$ like spherical melon, contained 6-16 seeds.

\section{Salt tolerance experiments}

The propagated seedlings grew for five months with exposure to normal temperature and sunlight in a controlled glass house. The mean temperature was $24.1{ }^{\circ} \mathrm{C}$. A seawater solution was prescribed by liquefying commercial salt powder (Marine Salt, Singapore) to make 0\% and 3\% (equal to seawater salinity level) salt concentrations following the manufacturer's protocol. Salinity in this term was denoted as the mass of salt powder/weight of the solution (Basyuni et al. 2012b). The salinity level in each pot treatment was verified weekly during the experiments by an S/Mill-E salinity refractometer (Atago Co., Ltd, Tokyo, Japan) and was regulated by adding tap water or pure water to the control treatment $(0 \%)$ or pure water to the salt treatments to recompense water lost due to evapotranspiration. Three plants in a detached pot, i.e., five bottle pots per species per salinity treatment, were grown for five months. After five months of cultivation, the three species of mangrove seedlings were collected and splashed, and then the leaves and roots were stored at $-20{ }^{\circ} \mathrm{C}$ for further analysis.

\section{Chemicals}

A mixture of dolichol $\left(\mathrm{C}_{95}-\mathrm{C}_{110}\right)$ standard compounds was isolated from horse testicles together with a combination of polyprenol $\left(\mathrm{C}_{90}-\mathrm{C}_{100}\right)$ as previously reported (Basyuni et al. 2017a). These mixtures were used to classify the polyisoprenoids that were traced in this work. A mixture of dolichol $\left(\mathrm{C}_{95}-\mathrm{C}_{110}\right)$ standard derived from skipjack tuna livers (Ishiguro et al. 2014) was also used in this study. The description of the family parallel to polyprenols or dolichols was carried out in at least three independent repetitions. Silica gel 60 TLC plates and reversed-phase silica RP-18 HPTLC plates were obtained from Merck. All of the other chemicals and solvents were of reagent grade (Merck).

\section{Procedures}

\section{Isolation of polyisoprenoid alcohols}

The protocol for the separation of polyisoprenoids was done as foregoing reported (Sagami et al. 1992; Basyuni et al. 2016). The leaves and roots of the three mangrove species were kept on an oven at $60{ }^{\circ} \mathrm{C}$ for two days. The dried tissue ( $2 \mathrm{~g}$ each) was crushed into a fine powder and submerged in chloroform/methanol $(2 / 1, \mathrm{v} / \mathrm{v})$ solvent for two days. The lipid extract of the leaves and roots was saponified at $65^{\circ} \mathrm{C}$ for $24 \mathrm{~h}$ in $50 \%$ ethanol containing $2 \mathrm{M}$ $\mathrm{KOH}$. The unsaponifiable lipids of each tissue sample were extracted with hexane, and the organic solvent was evaporated and re-dissolved in hexane. The leaf $(\approx 100 \mu \mathrm{g})$ and root $(\approx 200 \mu \mathrm{g})$ extracts were applied to each TLC plate.

\section{Analysis by two-dimensional thin layer chromatography (2D-TLC)}

First-dimensional TLC was preformed for $45 \mathrm{~min}$ on a silica gel glass plate $(20 \mathrm{~cm} \times 3 \mathrm{~cm})$ with a solvent system of toluene-ethyl acetate (9: 1) as previously described (Basyuni et al. 2016; 2017a). The second-dimension reversed-phase C-18 silica gel TLC was done with acetone as the solvent for about $45 \mathrm{~min}$. The position of the spaced polyisoprenoid alcohols being developed by 2D-TLC was determined and envisaged with iodine vapor (Basyuni et al. 2017b). To identify whether the family corresponds to dolichols or polyprenols, a dolichol or polyprenol standard was applied to the sample line of the first-dimensional TLC. In the case that one family was observed on 2D-TLC, the standard was also employed to the sample and generated with a solvent system as previously reported (Basyuni et al. 2016). The improved chromatographic images were acquired and digitally scanned with a Canon G-2000 series printer.

The polyisoprenoid family was confirmed by the correlation of mobility on TLC with that of authentic standards of dolichol or polyprenol used in the seconddimensional phase. The polyprenols and dolichols found on RP-18 HPTLC plates were measured using ImageJ ver. 1.46r (Schneider et al. 2012) with dolichol and polyprenol standards as references.

\section{Statistical analysis}

The data were statistically evaluated by Dunnett's to test between the two treatments: $3 \%$ salt concentration against $0 \%$ salt concentration. The significant value of $P<$ 0.05 was selected as the threshold of statistical significance. The analysis was carried out using the SAS 9.1 statistical software program (SAS Institute Inc., Cary, NC, USA)

\section{RESULTS AND DISCUSSION}

The effect of salinity concentration ( 0 and $3 \%$ ) on the existence and content of polyisoprenoids in three mangrove groups of salt management, namely salt-secreting ( $A$. officinalis), excluding (B. cylindrica), and accumulating (X. granatum) were analyzed by 2D-TLC (Basyuni et al. 
2017a, 2018a). Alteration of polyisoprenoids into polyprenols and dolichols differing in chain length was detected. The fundamental types of the polyprenols and dolichols distribution in the leaves and roots were grouped into two types (I and II) as previously reported (Basyuni et al. 2016, 2017a). In type I of polyprenols and dolichols distribution, the dolichols is more dominant while in type II, both were observed in leaves and roots and no dominance did occur. Type III which shows the predominance of polyprenols over dolichols was not observed in this study.

Table 1 and 2 show the polyisoprenoid and distribution in the leaves and roots of three species under 0 and $3 \%$ salinity. As depicted in Table 1, the highest total lipid content in leaves tissues was in found $X$. granatum under 0 and $3 \%$ salinity $(130.0 \mathrm{mg} / \mathrm{g} \mathrm{dw}$, respectively), and the lowest was found in B. cylindrica under 0 and $3 \%$ salinity (46.7 and $76.7 \mathrm{mg} / \mathrm{g} \mathrm{dw}$, respectively). Table 2shows that the highest total lipid in roots tissues were found in $A$. officinalis under $0 \%$ salinity $(83.3 \mathrm{mg} / \mathrm{g} \mathrm{dw})$ and $B$. cylindrica under $3 \%$ salinity $(120.0 \mathrm{mg} / \mathrm{g} \mathrm{dw})$, and the lowest was in X. granatum and A. officinalis (40.0 and 26.7 $\mathrm{mg} / \mathrm{g} \mathrm{dw}$, respectively under 0 and $3 \%$ salinity). $A$. officinalis leaves under $0 \%$, and $3 \%$ were found as type II, by contrast, B. cylindrica classified as type $\mathrm{I}$, and $X$. granatum observed as type II. These findings implied changes in two salinity level; polyisoprenoid, polyprenol, and dolichol contents were increasing or decreasing along with the enhanced salt concentration.
Table 2 shows that polyisoprenoids distribution in roots of $A$. officinalis was categorized as type I while that in $B$. cylindrica and $X$. granatum roots was classified as type II. The physiological role of polyisoprenoid in leaves and roots of mangrove differed between the two salinity levels. The contrasting responses in the investigations of isoprenoid, polyisoprenoid and osmotic stress have been reported in mangrove and halophyte plants. A previous study by Basyuni et al. (2009) shows that the mRNA levels of triterpenoid synthase genes and triterpenoid content increase in the root tissues and decrease in the leaves tissue of mangrove species Kandelia candel and Bruguiera gymnorrhiza as the salinity level increased. A similar report was shown by Basyuni et al. (2017a) in the polyisoprenoid content of leaves and roots of mangrove seedling. Furthermore, this result was also supported by previous study; in this circumstance, Silveira et al. (2009) reported a distinct osmotic adjustment of a halophyte plant Atriplex nummularia in response to salinity. The $A$. nummularia leaves showed a strong osmotic adjustment, however, it was less significant in the roots. In the present study, only $X$. granatum, an accumulating-salt species, displayed a consistent polyisoprenoid type between leaves and roots, type II, respectively. A. officinalis and $B$. cylindrica, on the other hand, in term of polyisoprenoid type they produced as type I or type II. This explanation may be coherent with the divergent and complex adaptation mechanism of halophyte plants including mangroves to the salinity level (Slama et al. 2015).

Table 1. Effect of salt concentration on the occurrence and distribution of polyisoprenoids in leaves of three mangrove species

\begin{tabular}{|c|c|c|c|c|c|c|c|c|c|c|c|}
\hline \multirow[t]{2}{*}{ Species } & \multirow{2}{*}{$\begin{array}{c}\text { Salinity } \\
(\%)\end{array}$} & \multirow{2}{*}{$\begin{array}{c}\text { TL } \\
(\mathrm{mg} / \mathrm{g} \mathrm{dw})\end{array}$} & \multirow{2}{*}{$\begin{array}{c}\text { PI } \\
(\mathrm{mg} / \mathrm{g} \mathrm{dw})\end{array}$} & \multirow{2}{*}{$\begin{array}{c}\text { Pol } \\
(\mathrm{mg} / \mathrm{g})\end{array}$} & \multirow{2}{*}{$\begin{array}{c}\text { Dol } \\
(\mathrm{mg} / \mathrm{g})\end{array}$} & \multicolumn{3}{|c|}{ \% total lipid } & \multicolumn{2}{|c|}{ \% polyisoprenoid } & \multirow[t]{2}{*}{ Type } \\
\hline & & & & & & PI & Pol & Dol & Pol & Dol & \\
\hline A. officinalis & 0 & $96.7 \pm 41.6$ & $92.7 \pm 29.8$ & $20.2 \pm 3.4$ & $72.5 \pm 5.1$ & 95.8 & 20.8 & 75.0 & 21.8 & 78.2 & II \\
\hline B. cylindrica & 0 & $46.7 \pm 20.8$ & $32.3 \pm 12.8$ & nd & $32.3 \pm 12.8$ & 69.1 & nd & 69.1 & nd & 100 & I \\
\hline$X$. granatum & 0 & $130.0 \pm 40.0$ & $14.5 \pm 7.9$ & $6.9 \pm 3.1$ & $7.6 \pm 4.9$ & 11.1 & 5.3 & 5.8 & 47.5 & 52.5 & II \\
\hline A. officinalis & 3 & $106.7 \pm 23.1$ & $47.2 \pm 13.2 a$ & $11.8 \pm 7.5 a$ & $35.4 \pm 13.0 a$ & 44.2 & 11.0 & 33.1 & 25 & 75 & II \\
\hline B. cylindrica & 3 & $76.7 \pm 20.8 a$ & $61.0 \pm 5.1 a$ & nd & $61.0 \pm 5.1 a$ & 79.5 & nd & 79.5 & nd & 100 & I \\
\hline$X$. granatum & 3 & $130.0 \pm 10.0$ & $38.5 \pm 19.6 a$ & $15.3 \pm 4.3 a$ & $23.2 \pm 4.8 a$ & 29.6 & 11.9 & 3.5 & 40.3 & 59.7 & II \\
\hline
\end{tabular}

Note: $\mathrm{nd}=$ not detected, $\mathrm{TL}=$ Total lipids, PI = Polyisoprenoids, Pol = Polyprenols, Dol = Dolichols, dw = dry weight. Data are stated as mean $\pm \mathrm{SD}(n=3)$ at least three independent experiments. ${ }^{a}$ Significantly different from $0 \%$ at $P<0.05$ using Dunnet's test. Total lipids are expressed as a fraction of a crude lipid estimated gravimetrically.

Table 2.Effect of salt concentration on the occurrence and distribution of polyisoprenoids in roots of three mangrove species

\begin{tabular}{|c|c|c|c|c|c|c|c|c|c|c|c|}
\hline \multirow[t]{2}{*}{ Species } & \multirow{2}{*}{$\begin{array}{l}\text { Salinity } \\
(\%)\end{array}$} & \multirow{2}{*}{$\begin{array}{c}\text { TL } \\
(\mathrm{mg} / \mathrm{g} \mathrm{dw})\end{array}$} & \multirow{2}{*}{$\begin{array}{c}\text { PI } \\
(\mathrm{mg} / \mathrm{g} \mathrm{dw})\end{array}$} & \multirow{2}{*}{$\begin{array}{c}\text { Pol } \\
(\mathrm{mg} / \mathrm{g})\end{array}$} & \multirow{2}{*}{$\begin{array}{c}\text { Dol } \\
(\mathrm{mg} / \mathrm{g})\end{array}$} & \multicolumn{3}{|c|}{ \% total lipid } & \multicolumn{2}{|c|}{ \% polyisoprenoid } & \multirow[t]{2}{*}{ Type } \\
\hline & & & & & & PI & Pol & Dol & Pol & Dol & \\
\hline A. officinalis & 0 & $83.3 \pm 30.6$ & $33.6 \pm 8.8$ & nd & $33.6 \pm 8.8$ & 40.3 & nd & 40.3 & nd & 100 & I \\
\hline B. cylindrica & 0 & $46.7 \pm 23.1$ & $41.2 \pm 10.4$ & $16.6 \pm 4.9$ & $24.6 \pm 5.5$ & 88.2 & 35.5 & 52.6 & 40.4 & 59.7 & II \\
\hline$X$. granatum & 0 & $40.0 \pm 20.0$ & $11.6 \pm 2.87$ & $3.2 \pm 1.6$ & $8.4 \pm 1.3$ & 29.1 & 7.9 & 21.2 & 27.2 & 72.8 & II \\
\hline A. officinalis & 3 & $26.7 \pm 5.8 a$ & $21.4 \pm 3.5$ & nd & $21.4 \pm 3.0$ & 80.1 & nd & 80.1 & nd & 100 & I \\
\hline B. cylindrica & 3 & $120.0 \pm 26.5 a$ & $96.5 \pm 23.6 a$ & $60.3 \pm 8.1 a$ & $36.2 \pm 11.6$ & 80.4 & 50.2 & 30.1 & 62.5 & 37.5 & II \\
\hline$X$. granatum & 3 & $73.3 \pm 11.5 a$ & $37.4 \pm 14.4 a$ & $32.8 \pm 6.1 a$ & $4.6 \pm 4.2 a$ & 51.1 & 44.8 & 6.2 & 87.7 & 12.2 & II \\
\hline
\end{tabular}

Note: $\mathrm{nd}=$ not detected, $\mathrm{TL}=$ Total lipids, PI $=$ Polyisoprenoids, Pol $=$ Polyprenols, Dol $=$ Dolichols, dw $=$ dry weight. Data are stated as mean $\pm \mathrm{SD}(n=3)$ at least three independent experiment. ${ }^{a}$ Significantly different from $0 \%$ at $P<0.05$ using Dunnet's test 
Table 3. Carbon-chain lengths of polyprenol and dolichol occurring in three mangrove seedlings

\begin{tabular}{|c|c|c|c|c|}
\hline Species & Tissue & Salinity $(\%)$ & Polyprenol* & Dolichol* $^{*}$ \\
\hline A. officinalis & Leaves & 0 & 5560 & 65707580859095100105110115120125130 \\
\hline B. cylindrica & Leaves & 0 & nd & 9095 \\
\hline$X$. granatum & Leaves & 0 & 6065 & 808590 \\
\hline A. officinalis & Leaves & 3 & 4550 & 65707580859095100105110115120125130135140 \\
\hline B. cylindrica & Leaves & 3 & nd & 808590 \\
\hline$X$. granatum & Leaves & 3 & 6065 & 808590 \\
\hline A. officinalis & Roots & 0 & nd & 80859095100105 \\
\hline B. cylindrica & Roots & 0 & nd & 808590 \\
\hline$X$. granatum & Roots & 0 & 7580859095100 & 7580859095100105 \\
\hline A. officinalis & Roots & 3 & nd & 7580859095 \\
\hline B. cylindrica & Roots & 3 & nd & 80859095 \\
\hline$X$. granatum & Roots & 3 & 7580859095 & 7580859095100 \\
\hline
\end{tabular}

Note: $*$ The numbers refer to the carbon-chain length of polyisoprenoid alcohols. nd= not detected

Table 3 summarizes the carbon-chain length in the leaf and root tissues of three mangrove species under $0 \%$ and $3 \%$ salinity. There was no significant change in polyisoprenoid composition in leaf tissues under 0 and $3 \%$ salinity level. Polyprenol with small different chain lengths as a shorter chain length of polyprenol was observed in $A$. officinalis under $0 \%$ salinity $\left(\mathrm{C}_{55}-\mathrm{C}_{60}\right)$ and $3 \%$ salinity $\left(\mathrm{C}_{45}\right.$ $\mathrm{C}_{50}$ ). On the other hand, carbon chain length of dolichol in B. cylindrica under $0 \%$ and $3 \%$ salinity level, respectively, $\mathrm{C}_{90}-\mathrm{C}_{95}$ and $\mathrm{C}_{80}-\mathrm{C}_{90}$. Salt stress increased the dolichols composition in A. officinalis leaves. Dolichol with a longer chain length was detected under $3 \%$ salt concentration (Table 3). A similar case was found in roots tissues, where the content and the chain length of dolichols of $A$. officinalis decreased with salt concentration $\left(\mathrm{C}_{80}-\mathrm{C}_{105}\right)$ under $0 \%$ salinity, and $\mathrm{C}_{75}-\mathrm{C}_{95}$ under $3 \%$ salinity), but the polyprenol content and carbon chain length did increase in B. cylindrica roots (from $\mathrm{C}_{80}-\mathrm{C}_{90}$ to $\mathrm{C}_{80}-\mathrm{C}_{95}$ ). Polyprenol was only found in $X$. granatum roots with insignificant change of carbon chain lengths from $\mathrm{C}_{75}-\mathrm{C}_{100}$ to $\mathrm{C}_{75}-\mathrm{C}_{95}$.

Figure 1-3 depict the two-dimensional TLC chromatograms of polyisoprenoid from leaves and roots of A. officinalis, B. cylindrica, and $X$. granatum, under 0 and $3 \%$ salinity. Longer chain length of dolichol was found in A. officinalis under 0 , and $3 \%$ salt concentration $\left(\mathrm{C}_{65}-\mathrm{C}_{130}\right.$ and $\mathrm{C}_{65}-\mathrm{C}_{140}$, respectively). Ficaprenol, a shorter polyprenol with carbon chain length under $0 \%$ and $3 \%$ salinity of $\mathrm{C}_{55}-\mathrm{C}_{60}$ and $\mathrm{C}_{45}-\mathrm{C}_{50}$, respectively, was detected in leaves but not detected in root tissues. In B. cylindrica, $\mathrm{C}_{80}-\mathrm{C}_{95}$ dolichols were identified but polyprenols were not detected (Figure 2). In leaves of X. Granatum, both ficaprenols $\left(\mathrm{C}_{60}-\mathrm{C}_{65}\right)$ and longer-chain dolichols $\left(\mathrm{C}_{80}-\mathrm{C}_{95}\right)$ were detected in both salt concentrations (Figure 3) while in the root tissue of those species, $\mathrm{C}_{75}-\mathrm{C}_{105}$ dolichol was detected in $0 \%$ salinity level and $\mathrm{C}_{75}-\mathrm{C}_{100}$ dolichol was detected in $3 \%$ salinity level. Additionally, in roots of $X$. granatum, longer polyprenols $\left(\left(\mathrm{C}_{75}-\mathrm{C}_{95}\right.\right.$ and $\left.\mathrm{C}_{75}-\mathrm{C}_{100}\right)$ were also found in, respectively, 0 and $3 \%$ salinity level.

Shorter polyprenol (ficaprenols) was only detected in a secretor species of $A$. officinalis leaves, which supported our previous findings on the accumulated ficaprenols on non-secretor species of B. gymnorrhiza, and $K$. candel leaves under $3 \%$. The diverse salinity coping mechanism resulted in different chain lengths of polyisoprenoids from shorter to longer chain lengths of polyisoprenoid (Basyuni et al. 2016, 2017a). Quantities of ficaprenol have been shown in the old leaves of K. obovata (Basyuni et al. 2016) which stores salt in its yellow leaves. The increase ficaprenols is supported by previous results (Baczewska et al. 2014) concerning the accumulation of short-chain polyprenols $\left(\mathrm{C}_{45}-\mathrm{C}_{60}\right)$ of Tilia 'Euchlora' leaves under the increased soil salinity levels. Polyprenols with shorter carbon chain length have been identified in the Euphorbiaceae tribe (Swiezewska et al. 1994) and other families such as Lauraceae, Tiliaceae, and Magnoliaceae (Roslinska et al. 2002), soybean leaves (Kurisaki et al. 1997); in young and old rubber leaves (Tateyama et al. 1999); in spinach leaves (Sakaihara et al. 2000); and in the leaves of number of mangrove species (Basyuni et al. 2016, $2017 \mathrm{~b}$ ). The present study suggested the importance of investigation on the salt tolerance mechanism of different species or genera of mangrove plants.

The physiological role of polyisoprenoids remains unclear. Polyisoprenoids, analogous to earlier studies on triterpenes (Basyuni et al. 2009, 2012b), might control salinity stress with reference to the triterpene synthase gene as well as the physicochemical features of cell membranes by enhancing the permeability and adaptation to external stress (Inafuku et al. 2018; Basyuni and Wati 2017c). Dolichol contents were expanded in the roots of Coluria geoides and Cucumis sativus under severe abiotic stress conditions, including salinity, heavy metal, and low temperatures (Skorupinska et al. 2009). Likewise, dolichol content enhances the drought tolerance in A. thaliana (Zhang et al. 2008). These latter studies were parallel with our current findings in term of the accumulation of dolichols in three mangrove seedlings.

The dominance of dolichols over polyprenols and vice versa in some plant tissues in agreement with predominance dolichols over polyprenols in this study and other reports is still poorly understood. It has been shown that the polyisoprenoid distribution and dominance might 


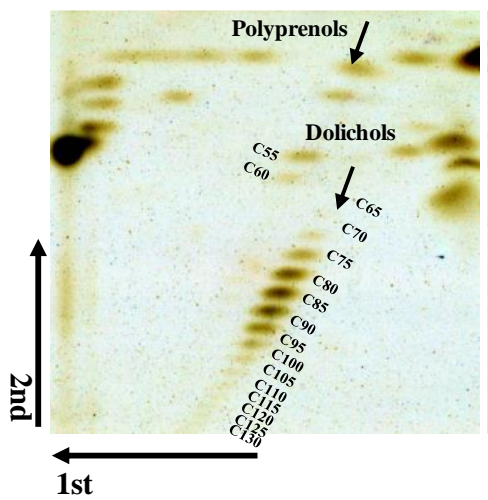

A

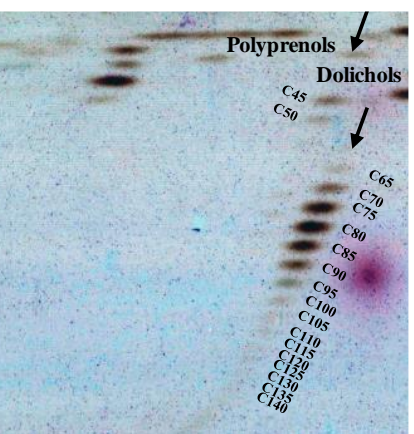

B

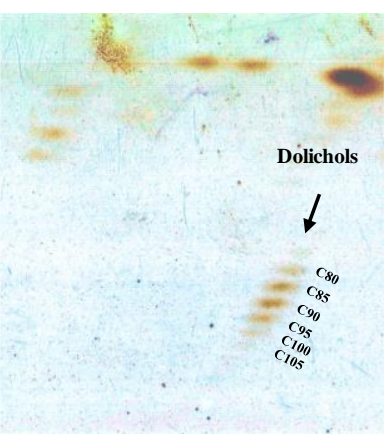

C

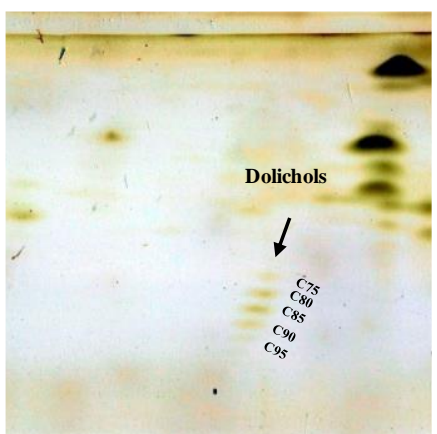

D

Figure 1. Two-plate TLC chromatograms of polyisoprenoids from A. officinalis: in leaves under 0\% (A) 3\% (B) salinity level, and in roots under 0\% (C) and in 3\% (D) salinity level. Data are from three independent experiments. The number shows the carbon chain length of polyisoprenoid alcohols. Arrow indicates the direction of TLC phase.

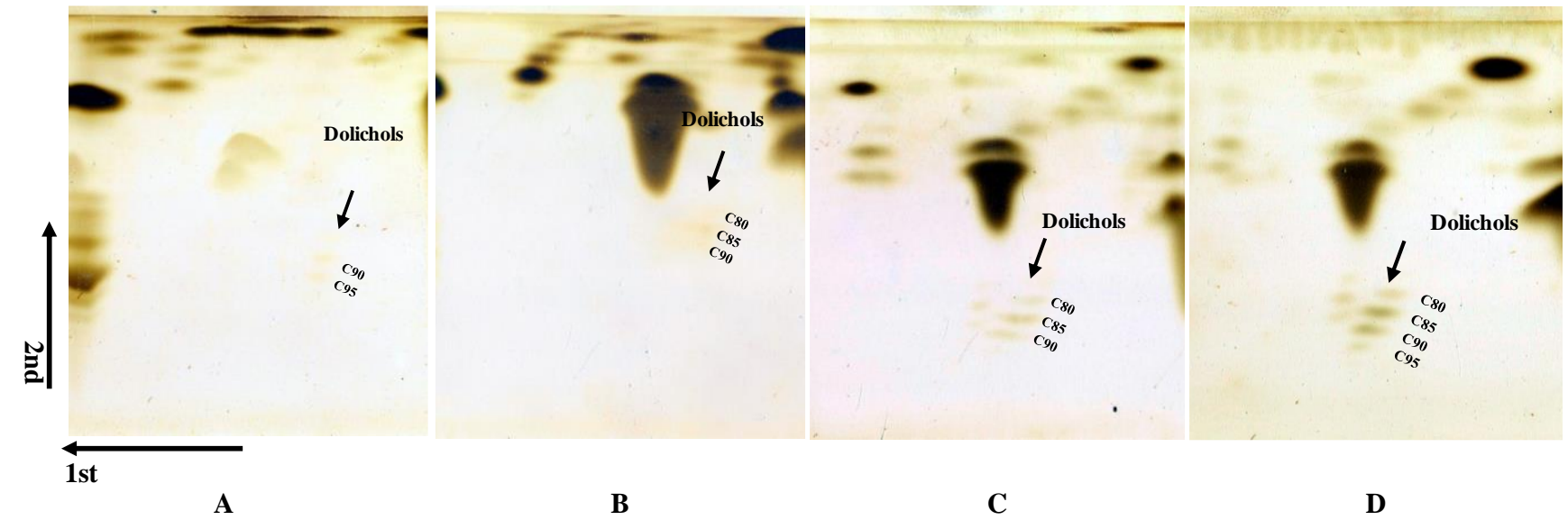

Figure 2. Two-plate TLC chromatograms of polyisoprenoids from B.cylindrica: leaves under 0\% (A) and 3\% (B) salinity levels, and in roots under $0 \%$ (C) and 3\% (D) salinity level. Data are from three independent experiments. The number shows the carbon chain length of polyisoprenoid alcohols. Arrow indicates the direction of TLC phase.

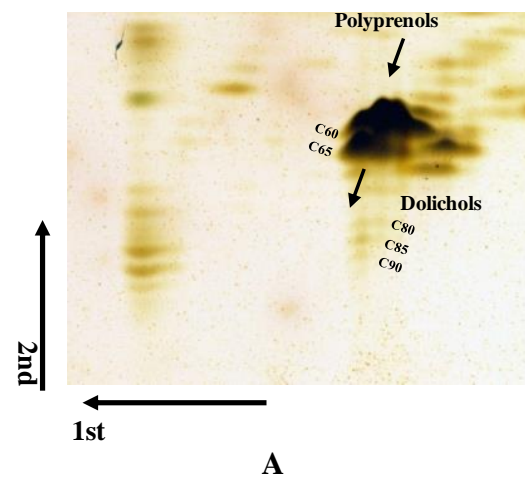

Figure 3. Two-plate TLC chromatograms of polyisoprenoids from X. granatum: in leaves under $0 \%$ (A) and 3\% salinity (B), and in roots under 0\% (C) and 3\% (D) salinity level. Data are from three independent experiments. The number shows the carbon chain length of polyisoprenoid alcohols. Arrow indicates the direction of TLC phase 
have resulted from the irregular stability of specific compounds of biosynthetic end-products (Skorupinska et al. 2007). Additionally, the predominance of dolichols over polyprenols in mangrove leaves and roots may be due to the existence of active enzymes of polyprenol reductase (Basyuni et al. 2018b, c, d) as a result of tropical or subtropical conditions such as climatic or environmental conditions. Recently, the predicted polyprenol reductase enzyme and its bioinformatics data had been reported from Kandelia obovata (Basyuni et al. 2018b,c).

The present study findings, therefore, well agreed with the view that there may be partly three different biosynthetic pathways responsible for the formation of shorter-chain polyprenols (ficaprenols-type), longer-chain polyprenols, and shorter and longer dolichols. These results suggested that the biosynthetic pathway from polyprenols to dolichols might be modulated by polyprenol reductase with firm precursor distinction to chain-length in mangrove plants. Recently, the existence of three fragments predicted polyprenol reductase genes had been shown in mangrove species of $K$. obovata (Basyuni et al. 2018b,c).

Moreover, a new polyprenol reductase (KoPPRD1) from $K$. obovata was found to be associated with other polyprenol reductases in the phylogenetic of plant kingdom (Basyuni et al. 2018d). These recent studies including this study, have confirmed the widespread polyisoprenoids in mangrove, and coastal plants were not polyprenols but dolichols. The polyprenol reductase which altered polyprenols into dolichols was elaborated in mangrove and coastal plants activities (Basyuni et al. 2016, 2017b, 2018a).

In conclusion, the present study results revealed a similar pattern and distribution of polyisoprenoid among mangrove groups of salinity coping mechanism (secreting, excluding, and accumulating). There was no substantial change in polyisoprenoid distribution types between leaves and roots of $A$. officinalis, B. cylindrica, and X. granatum seedlings: the groups were categorized as type I or II under $0 \%$ or $3 \%$ salt concentrations. The present study results also indicated that polyisoprenoids might play a protective function against salt concentration in the mangrove leaves and roots of three groups of salinity management.

\section{ACKNOWLEDGEMENTS}

This work was funded by an International Research Collaboration and Scientific Publication Grant 2016-2018 to MB from the Directorate General for Research and Community Service, Ministry of Research, Technology and Higher Education, Republic of Indonesia.

\section{REFERENCES}

Baczewska AH, Dmuchowski W, Jozwiak A, Gozdwoski D, Bragoszewska P, Dabrowski P, Swiezewska E. 2014. Effect of salt stress on prenol lipids in the leaves of Tilia 'Euchlora'. Dendrobiology 72: $177-186$
Basyuni M, Baba S, Inafuku M, Iwasaki H, Kinjo K, Oku H. 2009. Expression of terpenoid synthase mRNA and terpenoid content in salt-stressed mangrove. J Plant Physiol 166: 1786-1800.

Basyuni M, Baba S, Kinjo Y, Putri LA, Hakim L, Oku H. 2012a. Saltdependent increase in triterpenoids is reversible upon transfer to fresh water in mangrove plants Kandelia candel and Bruguiera gymnorrhiza. J Plant Physiol 169: 1903-1908.

Basyuni M, Baba S, Kinjo Y, Oku H. 2012b. Salinity increases the triterpenoid content of a salt secretor and a non-salt secretor mangrove. Aquat Bot 97: 17-23.

Basyuni M, Putri LAP, Nainggolan B, Sihaloho PE. 2014. Growth and biomass in response to salinity and subsequent fresh water in mangrove seedlings Avicennia marina and Rhizophora stylosa. J Manajemen Hutan Tropika 20: 17-25.

Basyuni M, Sagami H, Baba S, Iwasaki H, Oku H. 2016. Diversity of polyisoprenoid in ten Okinawan mangroves. Dendrobiology 75: 167175.

Basyuni M, Sagami H, Baba S, Putri LAP, Wati R, Oku H. 2017a. Salinity alters the polyisoprenoid alcohol content and composition of both salt-secreting and non-salt-secreting mangrove seedlings. Hayati J Biosci 24: 206-2014.

Basyuni, M., H. Sagami, S. Baba, and H. Oku. 2017b. Distribution, occurrence, dan cluster analysis of new polyprenyl acetones and other polyisoprenoids from North Sumatran mangroves. Dendrobiology78: 18-31.

Basyuni M, Wati R. 2017c. Bioinformatics analysis of the oxidosqualene cyclase gene and the amino acid sequence in mangrove plants. J Phys: Conf Ser 801: 012011.

Basyuni M, Wati R, Sagami H, Sumardi, Baba S, Oku H. 2018a. Diversity and abundance of polyisoprenoid composition in coastal plant species from North Sumatra, Indonesia. Biodiversitas 19: 1-11.

Basyuni M, Sagami H, Baba S, Oku H. 2018b. Genome sequence analysis of predicted polyprenol reductase gene from mangrove plant Kandelia obovata. IOP Conf Ser: Earth Environ Sci 130: 012039.

Basyuni M, Wati R, Sagami H, Oku H, Baba S. 2018c. Bioinformatics approach of three partial polyprenol reductase genes in Kandelia obovata. J Phys: Conf Ser 978: 012044.

Basyuni M, Baba S, Wati R, Sumardi, Sulistiyono N, Oku H, Sagami H. 2018d. Isolation and phylogenetic analysis of new predicted polyprenol reductase from mangrove plant (Kandelia obovata Sheue, HY Liu \& J. Yong). AIP Conf Proceed 2002: 020041. DOI: $10.1063 / 1.5050137$

Hogart PJ. 1999. The Biology of Mangroves. 1st ed., Oxford University Press, New York, USA.

Hoppe-Speer SC, Adams JB, Rajkaran A, Bailey D. 2011. The response of the red mangrove Rhizophora mucronata Lam. to salinity and inundation in South Africa. Aquat Bot 95: 71-76.

Inafuku M, Basyuni M, Oku H. 2018. Triterpenoid modulates the salt tolerance of lanosterol synthase deficient Saccharomyces cerevisiae, GIL77. Saudi J Biol Sci 25: 1-9

Ishiguro T, Morita-Fujimira Y, Shidoji Y, Sagami H. 2014. Dolichol biosynthesis: The occurrence of epoxy dolichol in skipjack tuna liver. Biochem Biophys Res Commun 451: 277-281.

Kurisaki A, Sagami H, Ogura K. 1997. Distribution of polyprenols and dolichols in soybean plant. Phytochemistry 44: 45-50.

Roslinska M, Walinska K, Swiezewska E, Chojnacki T. 2002. Plant longchain polyprenols as chemotaxonomic markers. Dendrobiology 47: 41-50.

Sagami H, Kurisaki A, Ogura K, Chojnacki T. 1992. Separation of dolichol from dehydrodolichol by a simple two-plate thin layer chromatography. J Lipid Res 33: 1857-1861.

Sagami H, Swiezewska E, Shidoji Y. 2018. The history and recent advances in research of polyprenol and its derivatives. Biosci Biotechnol Biochem 82: 947-955.

Sakaihara T, Honda A, Tateyama S, Sagami H. 2000. Subcellular fractionation of polyprenyl diphosphate synthase activities responsible for the syntheses of polyprenols and dolichols in spinach leaves. J Biochem128: 1073-078.

Schneider CA, Rasband WS, Eliceiri KW. 2012. NIH Image to ImageJ: 25 years of image analysis. Nature Methods 9: 671-675.

Silveira JAG, Araújo SAM, Lima JPMS, Viégas RA. 2009. Roots and leaves display contrasting osmotic adjustment mechanisms in response to NaCl-salinity in Atriplex nummularia. Environ Exp Bot 66: $1-8$ 
Skorupinska-Tudek K, Pytelewska A, Zelman-Femiak M, Mikoszewski J, Olszowska O, Gajdzis-Kuls D, Urbanska N, Syklowska-Baranek K, Hertel J, Chojnacki T, Swiezewska E. 2007. In vitro plant tissue cultures accumulate polyisoprenoid alcohols. Acta Biochim Pol54 $847-52$.

Skorupinska-Tudek KJ, Sternik J, Bajda A, Klobus G, Swiezewska E 2009. Changes in polyisoprenoid alcohols accumulation upon abiotic stress in plants. Presentation: Poster at Zjazd Polskiego Towarzystwa Biochemicznego.

Slama I, Abdelly C, Bouchereau A, Flowers T, Savoure A. 2015. Diversity, distribution, and roles of osmoprotective compounds accumulated in halophytes under abiotic stress. Ann Bot 115: 433447.

Swiezewska E, Danikiewicz W. 2005. Polyisoprenoids: Structure, biosynthesis, and function. Prog Lipid Res 44: 235-258.
Swiezewska E, Sasak W, Mankoowski T, Jankowski W, Vogtman T, Krajewska I, Hertel J, Skocylas E, Chojnacki T.1994. The search for plant polyprenols. Acta Biochim Pol 41: 221-260.

Tateyama S, Wititsuwannakul W, Wititsuwannakul D, Sagami H, Ogura K. 1999. Dolichols of rubber plant, ginkgo, and pine. Phytochemistry 51:11-15.

Tomlinson PB. 1986. The Botany of Mangroves.1st ed., Cambridge University Press, New York, USA.

Ye Y, Tam NFY, Lu CY, Wong YS. 2005. Effects of salinity on germination, seedling growth and physiology of three salt-secreting mangrove species. Aquat Bot 83: 193-205.

Zhang H, Ohyama K, Boudet J, Chen Z, Yang J, Zhang M, Muranaka T, Maurel C, Zhu JK, Gonga Z. 2008. Dolichol biosynthesis and its effects on the unfolded protein response and abiotic stress resistance in Arabidopsis. Plant Cell 20: 1879-898. 